\title{
PENDIDIKAN KARAKTER MELALUI REVOLUSI MENTAL DI ERA DISRUPTIF
}

\author{
Fitriatus Sholekhah
}

Email: fitriyahsholihah97@gmail.com

Fakultas Agama Islam Universitas Nurul Jadid Probolinggo

\begin{abstract}
The Indonesian nation is a developing country that is rich in its natural resources, but this country is still developing after 70 years of independence, the ideal of the Indonesian state is to make a nation that is civilized in accordance with norms and religion. What is wrong with this nation, so that the Indonesian people remain a developing country? Character education is the most important asset in a country, because the progress of a country depends on the character of the nation's children. In tackling character education that has deteriorated further, the mental revolution is the solution, a movement that was initiated by Indonesia's first president, Ir. Soekarno and was developed by President Jokowi as the 7th President of the Republic of Indonesia in his campaign in 2014. The current state of Indonesia is a character crisis for the nation, fighting between students, sexual violence, taking drugs, drugs and others. In welcoming the disruptive era where information technology is increasingly advanced and very easy. Where the nation's children still cannot distinguish between the good and the bad, the obligation of an educator who must guide and foster in the process of character development in the disruptive era.
\end{abstract}

Keyword: Character Education, Mental Revolution, Disruptif Era

\section{PENDAHULUAN}

Pendidikan merupakan bagian terpenting dalam kehidupan manusia yang sekaligus membedakan manusia dengan makhluk hidup lainnya, manusia dikarunia Tuhan akal dan pikiran, sehingga manusiadapat menyaring, memilih dan membedakan mana yang menurutnya baik dan buruk, mengetahui segala hakekat permasalahan dalam dirinya maupun kehidupan masyarakat dan bangsa. Tetapi berbeda dengan masyarakat yang dialami negara berkembang yakni negara Indonesia, dimana kasus kekerasan ataupun pelecehan seksual, 
perampokan, korupsi, narkoba sudah tidak asing lagi, baik dikalangan anakanak, dewasa hingga orang tua.

Dalam undang-undang pasal 3 No: 20 Th 2003 Bab II : menyebutkan untuk mengembangkan potensi peserta didik yang beriman serta bertaqwa kepada Tuhan Yang Esa , maka pendidikan nasional bertujuan mengembangkan kemampuan agar terbentuknya manusia yang berakhlaq mulia, kreatif, mandiri, serta bertanggung jawab dalam meneruskan cita-cita bangsa yang bermartabat.Tetapi mengapa masih banyak kejadian-kejadian yang tidak pantas terjadi seperti fenomena-fenomena yang dipaparkan diatas. Hal itu menimpa pada sistem dan proses pendidikan. Oleh karena itu, sudah saatnya indonesia melakukan perubahan. Tidak merubah secara drastis melainkan mencanangkan revolusi mental yang sesuai dengan pancasila dan UUD. ${ }^{1}$

Revolusi mental harus dimulai dari dunia pendidikan, melihat keadaan pendidikan yang mudah dan strategis dalam meneruskan mental generasi bangsa. Peran pendidikan karakterlah bagian terpenting menuju proses terbentuknya suatu generasi berkualitas unggul, yang berkarakter baik dan hal itu bisa mengubah sistem dan proses dalam pendidikan di negara Indonesia. Selain itu Pendidikan karakter tidak hanya membedakan sesuatu yang salah dan benar, tetapi juga memberi dan menanamkan suatu kebiasaan baik. Dengan begitu peserta didik menjadi paham ranah kognitif, afektik, psikomotorik seperti yang ada diteori toksonomi blom. Ranah kognitif lebih membedakan baik dan buruknya. Ranah afektif mampu merasakan nilai yang baik dan psikomotorik tentang kebiasaan, jika peserta didik terbiasa dengan hal-hal positif atau besikap baik maka mereka lebih spontan melakukannya. Jadi, pendidikan karakter adalah sebuah kunci dalam pembentukan anak bangsa yang berkualitas baik yang dipraktikkan dan dilakukannya dalam kehidupan sehari-hari. ${ }^{2}$

Pendidikan karakter juga termasuk suatu cara dalam membentuk seseorang menjadi orang baik. menjadi sesuatu yang penting untuk membentuk generasi yang berkualitas. Pendidikan karakter tidak lepas dengan kebiasaan yang dipraktikkan dan dilakukan. Pendidikan karakter . merupakan salah satu alat untuk membimbing seseorang menjadi orang baik. Yang membentuk generasi bangsa yang berkualitas, dan berkarakter unggul .Mental dan karakter buruk yang membuat bangsa Indonesia berada diambang

\footnotetext{
${ }^{1}$ Listyaning S Muhdi, Senowarsito, "Pendidikan Kecakapan Hidup ( Life Skills ) Melalui Child Friendly Teaching Model ( Cftm ) Sebagai Dasar Membangun Karakter Siswa," E-DIMAS Jurnal pengabdian kepada masyarakat 3, no. 1 (2012).

2Muhammad Kristiawan, "Telaah Revolusi Mental Dan Pendidikan Karakter Dalam Pembentukkan Sumber Daya Manusia Indonesia Yang Pandai Dan Berakhlak Mulia," Jurnal Ta'dib 18, no. 1 (2015): 1325.
}

65 | MODELING, Volume 6, Nomor 1, Maret 2019 
kemiskinan. Secara teori indonesia, negara yang kekayaannya berlimpah ruah, tentunya akan mudah menjadi negara maju karena membuat kesejahteraan pada rakyanya. Tetapi pada kenyataannya tidak, Dari tahun 1945 saat kemerdekaan Indonesia sampai sekarang, Indonesia tetap menjadi negara berkembang. Padahal banyak negara-negara tetangga yang sudah maju dan tidak memiliki SDA (Sumber Daya Alam) sekaya Indonesia. Sudah terbukti majunya suatu negara bukan hanya SDA nya yang berlimpah ruah melainkan masyarakatnya yang menanam sifat kejujuran, tanggung jawab, dan kerja keras. $^{3}$

Akhir-akhir ini sering kita mendengar era disruptif pada acara seminar atau media sosial. Minggu, 26 agustus 2018 menteri ketenagakerjaan Republik Indonesia bapak Muhammad Hanif Dhakiri,Menghadiri kuliah tamu yang bertempat diaula kampus Nurul jadid paiton probolinggo. "bermodalkan sarjana saja tidak cukup membuat orang berhasil dan sukses, tetapi juga dibutuhkan sesuatu hal yang baru, kreatifitas dan harus responsif dalam menyambut perubahan. Kalau kita tidak melakukan sesuatu hal baru dalam artian diam ditempat, maka kita akan tertinggal dari negara-negara diluar sana yang sudah jauh sebelumnya mempersiapkan dan menyambut era disruptif. oleh karena itu santri dan mahasiswa harus kreatif, inovatif dan responsif dalam menghadapi tantangan dan peluang kedepan. Ujar bapak hanif dalam orasinya"4.

Era disruptif, yakni era dimana komunikasi dan teknologi semakin maju, informasi tidak lagi dibendung, sumber informasi tidak hanya diperoleh dari satu atau dua media saja, melainkan ada puluhan, ratusan bahkan ribuan, dan itu dapat menjadi pembawa informasi dan pengetahuan baru bagi peserta didik. ${ }^{5}$ Sebagai pendidik dituntut mengejar arus perubahan yang relatif cepat. Dimana peserta didik masih belum bisa memilih dan membedakan sesutu yang baik dan buruk, untuk dirinya sendiri atau orang lain, jadi tugas pendidik untuk membimbing dan mampu mengarahkan peserta didik agar tetap terarah. Bukan hanya materi dalam kelas saja melainkan pembentukan karakter dan moral itu yang lebih penting. Sebenarnya bukan hanya tugas guru atau pendidik saja yang ikut serta melainkan orang tua, masyarakat, dan

\footnotetext{
${ }^{3}$ Nasrullah, “Pembentukan Karakter Siswa Melalui Pendidikan Agama Islam” 18 juni (2015): 67-82.

${ }^{4}$ Berita Universitas Nurul Jadid paiton probolinggohttps://www.timesindonesia.co.id/read/181203/20180826/153227/menaker-ri-isi-

kuliah-tamu-di-unuja-probolinggo-ini-

pesannya/https://www.timesindonesia.co.id/read/181203/20180826/153227/menaker-ri-isikuliah-tamu-di-unuja-probolinggo-ini-pesannya/

${ }^{5}$ Muhammad kristiawan, "Telaah Revolusi Mental Dan Pendidikan Karakter Dalam Pembentukkan Sumber Daya Manusia Indonesia Yang Pandai Dan Berakhlak Mulia," jurnal ta'dib 18 juni (2015): 1425.
}

MODELING, Volume 6, Nomor 1, Maret 2019 | 66 
lingkungan dimana mereka tinggal, Percuma saja jika guru membimbing karakter peserta didik jika didalam rumahnya orang tua tidak mencerminkan karakter yang baik. Begitu sebaliknya, Jadi semua beriring bersamaan dalamproses terbentuknya karakter anak bangsa untuk terciptanya generasigenerasi yang unggul dan berkualitas di negara Indonesia.

Mengapa perlu pendidikan karakter yang harus direvolusi mental? Karena diera disruptif teknologi informasi yang semakin canggih dimana anak bangsa tidak memanfaatkan hal itu dengan sebaik-baiknya dengan perbuatan yang positif malah sebaliknya menyalahgunakan hingga terjadi kekerasan seksual, narkoba, tawuran dan lain-lainnya, sudah mewakili mengapa penulis membahas ini, dalam penjelasan diatas dapat diambil secara garis besar, bahwa adanya revolusi mental yakni Mengubah mental peserta didik dan masyarakat bangsa secara revolusioner sebab terjadinya gejala krisis nilai dan karakter. ${ }^{6}$ Melihat keadaan karakter dan gejala krisis moral bagi anak bangsa yang semakin menipis dan merosot, jika keadaan ini dibiarkan saja maka bangsa Indonesia akan rusak dan dijajah oleh perkembangan yang semakin pesat yakni di era disruptif.

\section{Era Disruptif: Tantangan Pendidikan Karakter}

Dalam Pancasila dan UUD 1945 Pasal 2 UU No 20 Tahun 2003 tentang pendidikan merupakan peran yang strategis dalam menunjang kemajuan sebuah bangsa. Di pasal III UU No 20 Tahun 2003 fungsi pendidikan nasional adalah mengembangkan kemampuan dan membentuk watakdalam peradaban bangsa yang bermartabat dan mencerdaskan kehidupan bangsa. ${ }^{7}$

Pendidikan merupakan suatu proses untuk melatih peserta didik dalam mengembangkan potensi dan pengetahuan yang dimiliki oleh peserta didik melalui sejumlah pengalaman belajar untuk menjadikan dirinya sebagai agent of change. ${ }^{8}$ Karena dengan pendidikan seseorang bisa ber pola pikir maju dan mempunyai pemikiran yang berkualitas sehingga pendidikan sangat penting bagi peserta didik maupun orang dewasa.

Secara arti, karakter adalah kebiasaan. Sedangkan menurut para ahli psikologis, karakter sebagai kebiasaan yang mengarahkan pada seorang individu untuk berbuat sebuah tindakan. Jika karakter bisa di deteksi, maka dapat di deteksi pula bagaimana saat individu akan bersikap waktu kondisikondisi tertentu. Dilihat dari makna berarti karakter dan akhlak tidak memiliki

\footnotetext{
${ }^{6}$ Nova Mega Persada and Suwito Eko Pramono, "Pelibatan Orang Tua Pada Pendidikan Anak Di SD Sains Islam Al Farabi Sumber Cirebon" 6, no. 405 (2017): 100-108.Hal. 123.

${ }^{7}$ Gerakan Revolusi et al., "Membumikan Revolusi Mental," Jurnal Borneo Administrator 11, no. 1 (2016): 121-128.

${ }^{8}$ Agus Sutono, 'Meneguhkan Pancasila Sebagai Filsafat', Jurnal Ilmiah CIVIS, 1.Januari (2015), 666-78.
}

67 | MODELING, Volume 6, Nomor 1, Maret 2019 
perbedaan. Kedua-duanya memiliki pengertian yang sama yakni sebagai suatu yang terjadi spontan tanpa pemikiran karena sudah tertanam dalam alam bawah sadarnya. ${ }^{9}$

Bukan hanya pendidikan saja yang penting melainkan Pendidikan karakter, telah terbukti bahwa pendidikan karakter menjadi sorotan dalam beberapa negara berkembang dan maju didunia,dalam mempersiapkan generasigenerasi penerus bangsa yang berkualitas unggul. Bukan hanya kepentingan individu saja melainkan kepentingan suatu negara tersebut.10

Menurut Thomas lickona dalam pendidikan karakter dapat membentuk kepribadian dengan watak seseorang melalui budi pekertinya, yang hasilnya dapat dilihat dalam perilakunya setiap hari dalam tindakan yang nyata yaitu bertingkah laku baik, berkata jujur, mempunyai rasa bertanggung jawab, kerja keras dan saling menghormati.11 Pendidikan karakter juga dikelompokan melalui tiga hal; (1) nilai moral atau nilai akhlaq yaitu akhlaq terhadap Tuhan Yang Esa dan mengenal Tuhan sebagai penciptaNya dan meminta tolong kepadaNya; (2) Akhlak terhadap diri sendiri, orang tua teman sebaya dan orang yang lebih muda;(3) aklaq terhadap makhluk hidup ciptaan tuhan misal: mengembangkan sumber daya alam, ikut serta dalam melindungi suaka marga satwa, dan melestarikan cagar alam. ${ }^{12}$

Dapat ditarik kesimpulann bahwa pendidikan karakter ialah akhlaq dan budi pekerti yang berkepribadian khusus dengan nilai-nilai baik yang tidak hanya mengajarkan mana perbuatan baik atau buruk melainkan menanamkan kebiasaan baik atau terpuji. Pendidikan karakter ini membawa tujuan yang sama dengan pendidikan moral dan akhlaq yakni merubah seorang menjadi pribadi yang lebih baik lagi, bagaimana? dengan pendidikan karakter seorang bisa menjamin keberhasilannya dalam bergaul ditengah masyarakat dengan baik. Penulis berharap dengan pendidikan karakter di era sekarang ini hilangnya kebiasaan menyontek, malas-malasan, tawuran antar pelajar, ataupun masyarakat, penyalahgunaan narkoba dan lain-lain.

Negara Indonesia adalah termasuk negara terkaya Sumber daya alamnya dibandingkan dengan negara-negara lain. Berdasarkan data World Education Ranking yang diterbitkan Organisation for Economic Cooperation

\footnotetext{
${ }^{9}$ Adelina Yuristia, ““ Keterkaitan Pendidikan, Perubahan Sosial Budaya, Modernisasi Dan Pembangunan"', Jurnal Program Studi Pendidikan Ilmu Pengetahuan Sosial, 1.1 (2017), 1-17.

${ }^{10}$ Sri Haryati, "Pendidikan Karakter Dalam Kurikulum 2013," http://lib. untidar. ac. id/wp, 2017.

${ }^{11}$ Dalmeri, "Pendidikan Untuk Pengembangan Karakter (Telaah Terhadap Gagasan Thomas Lickona Dalam Educating for Character)," Al-Ulum 14, no. 1 (2014): 269-288, https://www.researchgate.net/publication/290920065_PENDIDIKAN_UNTUK_PENGEMBANGAN_KAR AKTER_Telaah_terhadap_Gagasan_Thomas_Lickona_dalam_Educating_for_Character.

${ }^{12} \mathrm{Abd}$ Khaliq, 'Pendidikan Karakter Dalam Perspektif Kitab Ayyuhal Walad, Konstruksi Pemikiran Imam Al-Ghazali', Al-Ibrah, 2.Mei (2017), 88-112.
} 
and Development (OECD, 2015), negara indonesia menempati nomer 69 dari 75 negara dan Posisi tertinggi diraih oleh negara singapura. ${ }^{13}$ Bisa dilihat bahwa, bukan Sumber daya alamlah yang menjamin majunya suatu negara, melainkan pendidikan disertai karakter dan morallah yang menjamin maju tidaknya negara tersebut.

Negara-negara maju diluar sana sudah banyak membuktikan dalam mempersiapkan generasi bangsa yang berkualitas dan unggul tidak hanya mengandalkan IQ saja melainkan pendidikan karakter yang ada dilingkungan rumah maupun didunia pendidikan. jika karakter anak bangsa dinegara tersebut baik maka kualitas negara tersebut baik, jika sebaliknya semakin buruk karakter anak bangsa dinegara tersebut maka kualitas yang dimiliki negara tersebut minim. Sebelum mengenal dunia pendidikan yang ada dilingkungan sekolah, tugas orang tua untuk membentuk karakter anak sehingga mereka bisa menerapkan dilingkungan sekolah nanti ketika anak sudah masuk didunia pendidikan.

Pendidikan karakter bukan hanya anak-anak saja yang membutuhkannya melainkan orang dewasa bahkan orang tua juga. Kenapa? Dengan semakin tingginya tingkatan kualitas pendidikan karakter seseorang, semakin tinggi pula kualitas hidupnya yang akan menjamin keberhasilan pergaulan dimasyarakat.14 Jadi bukan kalangan anak-anak saja yang membutuhkan pendidikan karakter melainkan seluruh masyarakat bangsa juga membutuhkannya, Dalam meningkatnya kemaslahatan sosial dan perkembangan negara tersebut.

Pendidikan karakter yang ada dilembaga formal khususnya sekolah memiliki tujuan tersendiri yakni mempererat dalam mengembangkan nilainilai kehidupan, mengoreksi perilaku peserta didik yang tidak sesuai bagi nilainilai dan norma, membangun komunikasi yang baik dengan keluarga maupun masyarakat demi menjadi kepribadian yang baik dan menanamkan tanggung jawab bagi peserta didik untuk terbentuknya pendidikan karakter. ${ }^{15}$

Pendidikan karakter bukanlah suatu materi yang bisa dibaca atau dicatat dan juga tidak dapat dievaluasi dalam jangka waktu yang singkat,melainkan sebuah pembelajaran yang diterapkan dalam kehidupansehari-harinya kepada peserta didik. Baik dilingkungan sekolah, lingkungan keluarga ataupun lingkungan masyarakat melalui proses

\footnotetext{
${ }^{13 R i z a}$ Yonisa Kurniawan, 'Identifikasi Permasalahan Pendidikan Di Indonesia Untuk Meningkatkan Mutu Dan Profesionalisme Guru', Konvensi Nasional Pendidikan Indonesia (Konaspi), Viii.October (2016), 1415-20.Hal. 1415.

${ }^{14}$ Saiful Bahri, 'Implementasi Pendidikan Karakter Dalam Mengatasi Krisis Moral Di Sekolah', Jurnal TA'ALLUM, 3.1 (2015), 57-76.Hal. 64.

${ }^{15}$ Sadam Fajar Shodiq, "Pendidikan Karakter Melalui Pendekatan Penanaman Nilai Dan Pendekatan Perkembangan Moral Kognitif," At-Tajdid : Jurnal Ilmu Tarbiyah 1, no. 1 (2017): 14-25.
}

69 | MODELING, Volume 6, Nomor 1, Maret 2019 
pembiasaan, keteladanan yang dilakukan secara berkesinambungan. Tugas dan sebuah tanggung jawab antara orang tua, guru, masyarakat dalam proses berhasilnya pendidikan karakter. ${ }^{16}$

Realita permasalahan bangsa Indonesia sekarang yakni merosotnya nilai etika, kurangnya kesadaran terhadap nilai-nilai budaya, dan melemahnya kemandirian bangsa. Pembangunan karakter merupakan cita-cita bangsa Indonesia yang didasari oleh pancasila UUD 1945. Untuk terciptanya pembangunan karakter seperti yang diinginkan bangsa Indonesia maka pemerintah mewujudkan visi pembangunan nasional dalam menempatkanpendidikan karakter sebagai landasan yakni"mewujudkan masyarakat berakhlak mulia, bermoral, beretika, berbudaya, dan beradab berdasarkan falsafah Pancasila" sebagai salah satu program prioritas. ${ }^{17}$

Di era disruptif dimana tantangan teknologi yang semakin maju yang memudahkan hidup manusia. Banyak hal terselesaikan dengan smartphone, misal ketika butuh informasi tinggal klik google map untuk jawabannya. Ketika tidak memahami bahasa asing tinggal klik di google translite. Dan banyak aplikasi belanja online yang menyediakan kebutuhan pokok hingga kebutuhan tersier. ${ }^{18}$ Selain itu Kemajuan ilmu dan teknologi informasi membuat gaya hidup dan mengubah cara pandang masyarakat yang baru. Peranan teknologi informasi telah membawa era baru di sistem pendidikan dalam perkembangan dunia pendidikan. ${ }^{19}$ Didalam era ini bukan seorang peserta didik saja yang harus maju pemikiran dan teknologi, melainkan semua penduduk bangsa Indonesia harus semakin maju terhadap perkembangan zaman diera tersebut, untuk mensukseskan pendidikan karakter dan pasar dunia yang semakin bebas.

Disruptif adalah sebuah gangguan atau kekuatan mengganggu yang tak terlihat tetapi memiliki kekuatan pengaruh yang luar biasa. Anak lebih senang dengan dunia maya dan teman sebaya di banding berkawan dengan para guru dan orang tua. ${ }^{20}$ jika terjadi seperti ini maka peserta didik akan mengalami

\footnotetext{
${ }^{16}$ Nur Ainiyah, "Pembentukan Karakter Melalui Pendidikan Agama Islam," Jurnal Al-Ulum 13, no. 1 (2013): 25-38.

17Juliana Murniati, “Era Disrupsi : Tantangan Dan Peluang Bagi PT Anggota APTIK II . Era Disrupsi Dan Tantangannya Pada Pendidikan" (2017): 1-12.

${ }^{18}$ ismu tri parmi supinah, "Pengembangan Pendidikan Budaya Dan Karakter Bangsa Melalui Pembelajaran Matematika Di SD," Kementerian Pendidikan Nasional Badan Pengembangan Sumber Daya Manusia Pendidikan dan Penjaminan Mutu Pendidikan Pusat Pengembangan dan Pemberdayaan Pendidik dan Tenaga Kependidikan (PPPPTK) Matematika (2011).Hal. 1.

${ }^{19}$ Haris Budiman, "Peran Teknologi Informasi Dan Komunikasi Dalam Pendidikan," Al-Tadzkiyyah: Jurnal Pendidikan Islam 8, no. 1 (2017): 31-43.

${ }^{20}$ Iswan dan Herwina, "Penguatan Pendidikan Karakter Perspektif Islam Dalam Era Milineal IR. 4.0," PROSIDING Seminar Nasional Seminar Nasional Pendidikan Era Revolusi "Membangun Sinergitas dalam Penguatan Pendidikan Karakter pada Era IR 4.0" Universitas Muhammadiyah Jakarta, Indonesia, 24 Maret 2018 ISSN : 2621-6477 “Membangun Sinergitas dalam Penguata (2018): 21-42.
}

MODELING, Volume 6, Nomor 1, Maret 2019 | 70 
kesukaran dalam proses pergaulan dengan lingkungan masyarakat yang mengakibatkan kerusakan fatal bagi bangsa Indonesia jika seorang peserta didik tidak bisa memilah dengan kegiatan yang positif. Itulah tantangan bagi guru dan orang tua dalam menghadapi era disruptif.

Di era ini informasi yang tidak lagi dibendung, sumber informasi yang sangat mudah tidak hanya diperoleh satu atau dua saja melainkan puluhan, ratusan bahkan ribuan media menjadi pembawa pesan dan pengetahuan baru yang perubahannya terjadi begitu cepat. Didalam dunia pendidikan, anak usia dini juga menjadi sasaran perkembangan kemajuan teknologi dunia, Mereka begitu mudah dalam memperoleh pengetahuan dan informasi dengan teknologi modern. ${ }^{21}$

Kemajuan teknologi yang semakin canggih diera disruptif ini, tidak dapatdihindari bahwa dalam kehidupan sehari-hari manusia juga membutuhkannya karena kemajuan teknologi berjalan seiringan sesuai kemajuan ilmu pengetahuan dan mempermudah manusia dalam aktifitas kehidupannya, sehingga manusia bisa memanfaatkan teknologi dengan sebaikbaiknya.22 Selain sangat bermanfaat bagi orang banyak di dalam dunia pendidikan juga berdampak negatif, sebagai akibat dari berkembangnya teknologi informasi itu sendiri. ${ }^{23}$ dampak negatif teknologi informasi yakni semakin mudah pelanggaran HAKI (Hak Atas Kekayaan Intelektual), karena dengan semakin mudah mengakses data, semakin mudahlah melakukan kecurangan yakni menyebabkan plagiatis. ${ }^{24}$ Selain pemanfaatan teknologi yang digunakan pada hal negatif,Sosok yang seharusnya menjadi tokoh terpenting dalam perubahan dan perkembangan karakter berbanding terbalik dengan fenomena yang ada.

Kepala sekolah adalah pemimpin lembaga pendidikan yang memegang pengelolaan dalam mengembangkan sumber daya manusia dilembaganya, Oleh karena itu harus dibekali dengan jiwa kepimpinan, inovasi, skill dan kreatifitas yang tinggi agar lembaganya dapat berkembang maju dan pesat .25

Di sumatera utara beberapa siswa mendapat sebuah kunci jawaban dari oknum tertentu sejak pagi hari, siswa kemudian menyembunyikan dikaos kaki dan dasi. Kejadian terjadi pula di kota brebes, serikat guru brebes menemukan

\footnotetext{
${ }^{21}$ Persada and Pramono, "Pelibatan Orang Tua Pada Pendidikan Anak Di SD Sains Islam Al Farabi Sumber Cirebon." Hal. 101.

${ }^{22}$ Muhamad and Ngafifi, 'Kemajuan Teknologi Dan Pola Hidup Manusia Dalam Perspektif Sosial Budaya', Jurnal Pembangunan Pendidikan, 2.1 (2014), 33-47.

${ }^{23}$ Lies Sudibyo, "Peranan Dan Dampak Teknologi Informasi Dalam Dunia Pendidikan Di Indonesia," Widyatama 20, no. 2 (2011): 175-185.

24Ibid.Hal. 181.

${ }^{25}$ Hasan Baharun, "Peningkatan Kompetensi Guru Melalui Sistem Kepemimpinan Kepala Madrasah," At-Tajdid: Jurnal Ilmu Tarbiyah 6, no. 1 (2017): 1-25.
}

71 | MODELING, Volume 6, Nomor 1, Maret 2019 
siswa menyalin kunci jawaban dimusalla sebelum ujian berlangsung. Akan tetapi kecurangan tersebut sulit untuk membuktikannya karena melibatkan kepala sekolah dan panitia penyelenggara. ${ }^{26}$

Dalam pendidikan karakter dilingkungan sekolah, guru harus mempengaruhi peserta didik dalam menumbuhkan karakter baik. Guru harus menunjukkan sikap ramah, jujur dan keteladanan-keteladanan lainnya. Karena kewajiban guru untuk memberi contoh yang lebih baik bagi peserta didik. Misalnya dalam bertutur kata, menyampaikan materi dan berbagai hal lainnya. Tujuannya adalah membentuk warga negara dan peserta didik yang baik yang berbudi luhur. ${ }^{27}$

Kualitas dan watak guru mempengaruhi perkembangan peserta didik yang mampu berperan sebagai perencana (desainer), pelaksana (implementor) dan penilai (evaluator). ${ }^{28}$ Guru merupakan salah satu peran penting dalam perkembangan karakter anak yang berlangsung disekolah. Gurulah yang menghasilkan generasi bangsa yang berkualitas. Oleh karena itu amanah guru sangat besar yang dimana perilaku guru harus sesuai dengan nilai-nilai norma, agama dan pancasila. ${ }^{29}$

Perilaku dan kasus merokok tidak asing lagi bagi kalangan guru ataupun karyawan di lingkungan sekolah, para peserta didik dilarang merokok disekolah tetapi faktanya gurulah yang sering melanggar. Misalnya di kota depok tahun 2004 dilembaga formal SMP dari 1131 guru dan karyawan ditemukan sebanyak 21,8\% (247) orang merokok. Dan ditemukan 82,2 \% dari 247 orang yakni 203 orang merokok dilingkungan sekolah alasannya tidak ada peraturan merokok bagi guru dan karyawan disekolah.selain itu beberapa fenomena hal-hal yang tidak dipatut dicontoh yakni: membuang sampah sembarangan, berteriak dan lain-lain. Meskipun kelihatannya sangat sepele tetapi berakibat kerusakan bagi peserta didik. ${ }^{30}$

Fenomena krisis karakter yang terjadi dinegara bangsa Indonesia terjadi dan bahkan tidak asing lagi didengar contohnya Siswa SMP sering kali terjadi tawuran antar pelajar, ketika mereka masuk dijenjang SMA mereka bertambah meningkat, awalnya yang hanya mencaci hingga saling memukul bahkan ada yang menggunakan senjata tajam,hingga sering kali terjadi

\footnotetext{
${ }^{26}$ Huriah Rachmah, 'Nilai-Nilai Dalam Pendidikan Karakter Bangsa Yang Berdasarkan Pancasila Dan Uud 1945', E-Journal Widya Non-Eksakta, 1.1 (2013), 7-14.

${ }^{27}$ Imam Suyitno, 'Pengembangan Pendidikan Karakter Dan Budaya Bangsa Berwawasan Kearifan Lokal', Jurnal Pendidikan Karakter, 1.Februari (2012), 1-13.

${ }^{28}$ Lili Ng Chui Mi, 'Pelaksanaan Supervisi Klinis Kepala Sekolah Untukmeningkatkan Kinerja Guru Dalam Mengelola Pembelajaran Pada Sma Negeri 2 Sambas', Jurnal Visi Ilmu Pendidikan, 711-23.

${ }^{29}$ Miftah Mucharomah, "Guru Di Era Milenia Dalam Bingkai Rahmatan Lil Alamin," Edukasia Islamika 2, no. 2 (2017): 201-221.

${ }^{30}$ Rachmah, "Nilai-Nilai Dalam Pendidikan Karakter Bangsa Yang Berdasarkan Pancasila Dan Uud 1945."Hal. 8.
} 
pembunuhan. Pada giliran ditingkat perguruan tinggi mereka bertambah pembrani dan agresif, mengadakan demo besar-besaran, tidak hanya lawan sebaya bahkan aparat keamanaan pun mereka lawan. ${ }^{31}$

Orang tua adalah salah satu peran dalam perkembangan anak bangsa. Kewajiban orang tua memberikan yang terbaik untuk masa depan anak bangsa agar menjadikan sesosok anak bangsa yang bermanfaat dan berguna bagi negaranya. Upaya orang tua yakni memberikan motivasi belajar, mendidik watak anak agar menjadi insan yang baik yang berkarakter dan bermoral. ${ }^{32}$

Kejadian seorang murid yang baru saja diberi pelajaran akhlak dengan gurunya tentang sopan santun berbicara, " kalau berbicara yang halus dan jangan berbicara dengan kata-kata kotor", tetapi ketika dirumah orang tuanya tersebut terbiasa mengucapkan kata-kata kotor dengan mengobrol "namanama binatang" bahkan perilaku keseharian orang tua jauh dari norma sopan santun, seperti: berkata kotor, bertengkar dengan istri atau suami dengan memukul, menendang, tanpa disadari perilakunya dilihat oleh anak dan mempengaruhi perkembangan watak anak tersebut sehingga anak akan melakukan hal yang sama.33

Selain kepala sekolah, guru dan lembaga pendidikan ada hal penting yang berpengaruh dalam terbentuknya karakter anak bangsa yakni masyarakat yang berperan aktif dalam proses terbentuknya karakter anak bangsa. Tetapi kenyataanya mayarakat kurang peduli dengan kerakter anak bangsa yang semakin merosot misal: tawuran antar desa, sekolah maupun teman sebaya, minum-minuman keras dan memakai obat terlarang.

peristiwa tawuran pelajar di SMAN 70 dengan SMAN 6 yang melibatkan korban siswa yang bernama Alawy yusrianto putra; dua hari kemudian siswa yayasan karya 66 kampung melayu dan SMK Kartika Zeni mengakibatkan korban siswa tewas terkena sabetan senjata tajam. Kasus ini sangatlah merusak karakter dan moral anak bangsa. Bahkan masyarakat masih tetap acuh tak acuh dalam keadaan ini. ${ }^{34}$

dari penejelasan diatas dapat ditarik kesimpulan bahwa fenomenafenomena yang sangat merosot dari karakter moral bangsa melihat teknologi informasi yang semakin canggih seharusnya mempermudah dalam perkembangan pendidikan karakter anak bangsa tetapi malah

\footnotetext{
${ }^{31}$ Ahmad Nawawi, "Pentingnya Pendidikan Nilai Moral Bagi Generasi Penerus," INSANIA (Jurnal Pemikiran Alternatif Kependidikan) 16, no. 2 (2011).

${ }^{32}$ Mutmainnah, "Kontribusi Pola Asuh Orang Tua Dalam Pendidikan Karakter," DIKLUS Jurnal Pendidikan Luar Sekolah 16, no. 2 (2012).

${ }^{33}$ sugiyatno, "Kekerasan Di Sekolah Bagian Masalah Pendidikan Sosial- Emosional," Paradigma 9, no. V (2010): 29-42.

${ }^{34}$ Paul Suparno, "Pengembangan Karakter Untuk Anak Zaman Sekarang," https://core.ac.uk/download/pdf/45364404., 2012.
}

73 | MODELING, Volume 6, Nomor 1, Maret 2019 
sebaliknya,banyak sekali fenomena-fenomena yang tidak sesuai bahkan sudah merusak karakter generasi anak bangsa, para guru dan lembaga pendidikan yang seharusnya menjadi contoh teladan yang baik sangat melenceng, orang tua yang seharusnya mendidik dan mengontrol dalam perkembangan anaknya tetapi malah cuek dan lebih memilih pekerjaannya, sifat masyarakat yang apatis terhadap perilaku anak bangsa yang semakin menurun.

Pendidikan karakter yang diingankan bangsa Indonesia sekarang yakni menginginkan generasi muda yang berilmu pengetahuan tinggi dengan dibekali IMTAQ kepada Tuhan Yang Esa, berakhlak mulia, kreatif, cakap, dan menjadi warga negara yang menjalankan amanah serta bertanggung jawab dalam melaksanakan character building. ${ }^{35}$

Melihat perubahan yang sangat cepat diera disruptif ini tentu semua pihak yang bersangkutan yakni orang tua, guru dan masyarakat harus bekerja cepat dalam mengejar era ini, dengan kerja sama dan berkolaborasi dengan pihak untuk memperluas dan memperdalam peningkatan efisiensi pertumbuhan yang baik dalam menghadapi percepatan perubahan yang semakin cepat dan membuat semua pihak menjadi was-was dan khawatir. ${ }^{36}$

\section{Gagasan Revolusi Mental}

Revolusi mental istilah yang dicetuskan oleh soekarno presiden pertama Indonesia dalam pidato memperingati proklamasi kemerdekaan pada tanggal 17 agustus 1957, dan ditahun 2014 digagaskan kembali oleh presiden Joko Widodo. Revolusi mental adalah sesuatu gerakan hidup baru untuk menjadi manusia baru yang berhati putih atau bersih, berkemauan baja, bersemangat elang rajawali, dan berjiwa api. ${ }^{37}$ Semenjak pemerintahan baru jokowi istilah revolusi mental bukanlah suatu yang asing lagi. Mental tentang pikiran. Mentalitas juga berkaitan dengan cara pikir yang menjadi kebiasaanya dalam berpikir, kebiasaan dilakukan karena dengan pembiasaan. jadi, mentalitas dapat diubah dengan cara melakukan perubahan dari kebiasaan. Sehingga menjadi terbiasa dilakukan dan terjadi secara spontan. ${ }^{38}$

Revolusi menurut KBBI ialah suatu perubahan, Mental dapat diartikan cara pola pikir, cara memandang masalah, cara berperilaku dan bertindak. Makna

\footnotetext{
${ }^{35}$ Nur Ainiyah, "Pembentukan Karakter Melalui Pendidikan Agama Islam," Jurnal Al-Ulum (Jurnal StudiStudi Islam) IAIN Gorontalo 13, no. juni (2013): 25-38.

${ }^{36}$ Endang Fatmawati, "Disruptif Diri Pustakawan Dalam Menghadapi Era Revolusi Industri 4.0," Jurnal Iqra' 12, no. 1 (2018): 1-13.

${ }^{37}$ Ady Ferdian Noor, 'Gerakan Revolusi Mental Untuk Meningkatkan Pendidikan Kepribadian Warga Negara', Pedagogik Jurnal Pendidikan, 11.Maret (2016), 7-13. Hal. 9-10.

${ }^{38}$ Mohammad Syaifudin, Nurul Zuriah And Marhan Taufik, 'Revolusi Mental Melalui Model Pendidikan Karakter Bangsa Untuk Penguatan Kemandirian Pangan Dan Cinta Produk Indonesia', Jurnal Pendidikan Sains Sosial Dan Kemanusiaan, 9.November (2016), 221-34.Hal. 223.
}

MODELING, Volume 6, Nomor 1, Maret 2019 | 74 
luasnya revolusi mental adalah membongkar budaya-budaya yang sudah tertanam kuat yang kini menjadi hilang. ${ }^{39}$ Salah satunya sifat tidak bertanggung jawab, banyak peserta didik yang mengadakan tawuran antar pelajar maupun teman sebaya yang mengakibatkan permusuhan bahkan sampai terjadi pembunuhan.

Revolusi mental adalah suatu gerakan nasional yang mengubah cara pandang, pola pikir, nilai-nilai dalam mewujudkan indonesia yang berkeadaban, mandiri, dan berkepribadian. Revolusi mental juga bisa disebut gerakan hidup baru untuk perubahan bangsa indonesia menjadi negara yang bermartabat, berkualitas. ${ }^{40}$

Visi Gerakan Revolusi Mental

"Terwujudnya cita-cita bangsa yang berintegritas dan beretos kerja dalam semangat gotong royong dan menjadikan bangsa Indonesia yang berkeadaban" Misi Gerakan Nasional Revolusi Mental

1. Memperkuat nilai kesatuan yang utuh 2. Menegakkan aturan-aturan terhadap penyelenggara negara 3.Mempraktikkan dalam kehidupan masyarakat. 4. Melembagakan secara sistemik dan terstruktur pada penyelenggara negara dan masyarakat. 5.Memperluas keterlibatan penyelenggara negara dan masyarakat untuk membangun budaya dalam berintegritas, etos kerja, dan gotong royong. 41

Dapat dilihat diketerangan diatas bahwa visi misi gerakan revolusi mental yakni menginginkan bangsa Indonesia yang berintegritas,beretos kerja dan semangat dalam bergotong royong untuk membangun bangsa yang bermartabat dan berkualitas dalam persaingan era modern sekarang ini.

Revolusi mental suatu gerakan yang sudah di resmikan oleh pemerintah bahkan sudah masuk RPJMN (Rencana Pembangunan Jangka Menengah Nasional) 2014-2019.42 Revolusi mental mengacu pada nilai-nilai integritas, etos kerja, dan gotong royong demi membangun bangsa yang maju dan makmur berdasarkan pancasila. Dengan menginstruksikan:

1. Menteri Kabinet Kerja Republik Indonesia;

2. Sekretaris Kabinet;

3. Jaksa Agung RI;

4. PTNI(Panglima Tentara Nasional Indonesia);

5. Kepala Kepolisian Negara RI;

6. Kepala Lembaga Pemerintah Non Kementerian RI;

${ }^{39}$ Muhammad Kristiawan, "Telaah Revolusi Mental Dan Pendidikan Karakter Dalam Pembentukkan Sumber Daya Manusia Indonesia Yang Pandai Dan Berakhlak Mulia," jurnal ta'dib (2015). Hal. 21.

${ }^{40}$ Ady Ferdian Noor, "GERAKAN REVOLUSI MENTAL UNTUK MENINGKATKAN PENDIDIKAN KEPRIBADIAN WARGA NEGARA."Hal. 10.

${ }^{41}$ Ibid.

${ }^{42}$ Ibid. Hal. 10.

75 | MODELING, Volume 6, Nomor 1, Maret 2019 
7. Kepala Sekretariat Lembaga Negara;

8. Gubernur Dan wagub;

9. Bupati/Walikota;43

Presiden joko widodo telah mencanangkan revolusi mental sejak kampanye pada tahun 2014. Gerakan revolusi mental bukan hanya di Indonesia, di negara korea selatan pernah dilakukannya gerakan tersebut yang dikenal "saemul undong" yakni pembangunan bangsa dari desa yang berhasil dilakukan sejak tahun 1960. Tetapi banyak menteri dan aparat dibawah tidak mensetujuinya karena berbagai alasan-alasan. Gerakan revolusi mental sebaiknya melalui pendidikan dan penegakan hukum agar Indonesia bisa keluar dari masalah krisis karakter bangsa. ${ }^{44}$

Revolusi mental dizaman sebelum kemerdekaan adalah perjuangan fisik untuk melawan penjajah dan sekutu untuk merebut dan mempertahankan kembali kemerdekaan negara Republik Indonesia. 70 tahun indonesia merdeka dari para penjajah. Revolusi mental ini belum berakhir dan tak pernah berakhir, Tetapi revolusi mental di era selanjutnya bukan lagi dengan perang lagi tetapi membangun karakter jiwa bangsa yang bermartabat dan berkualitas. 45

Revolusi mental yang dilakukan dalam kehidupan sehari-hari pada era ini yakni untuk terbentuknya manusia yang berintegritas,beretos kerja, dan semangat dalam gotong royong.(1) Integritas yang terdiri dari perilaku jujur, ber amanah atau dapat dipercaya, berkarakter baik, dan memiliki rasa tanggung jawab;(2) etos kerja yang terdiri dari kerja keras, optimis dalam menghadapi semua hal, mampu menghasilkan hal-hal produktif, inovatif, dan berdaya saing; (3) gotong royong yang terdiri dari bekerja sama, rasa solidaritas tinggi, komunal, berorientasi dalam meninjau pada kemaslahatan kewargaan. ${ }^{46}$

\footnotetext{
${ }^{43}$ Republik Indonesia, 'Presiden Republik Indonesia', Instruksi Presiden Republik Indonesia Nomor 12 Tahun 2016 Tentang Gerakan Nasional Revolusi Mental, 2016, 1-9.Hal. 1.

${ }^{44}$ Direktorat Jenderal, Komunikasi Publik And Kementerian Komunikasi, Revolusi Mental, 2015. Hal. 7.

${ }^{45}$ Kementerian Kesehatan and Republik Indonesia, "Revolusi Mental: Membangun Jiwa Merdeka Menuju Bangsa Besar," www.depkes.go.id, 2018.

46Dodo Sutardi, 'Revolusi Mental Pada Lingkungan Pendidikan Desa Terpencil', Sekolah Dasar: Kajian Teori Dan Praktik Pendidikan, 2017, 59-68. Hal. 59.
} 
Kerangka Pikir Revolusi Mental

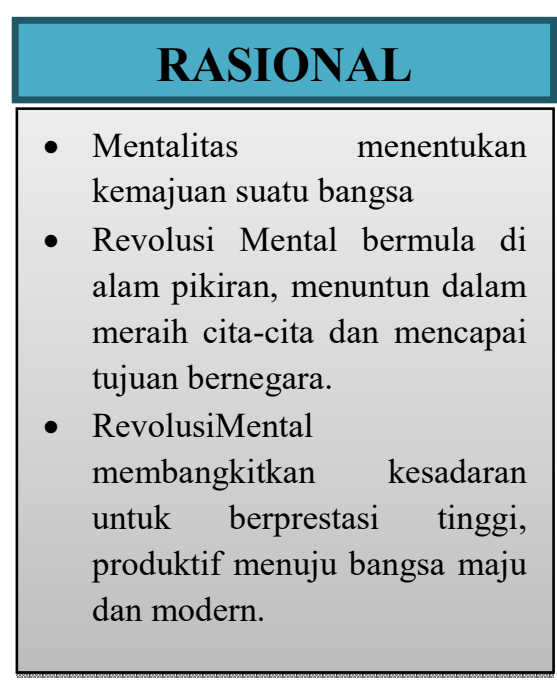

\section{MAKNA REVOLUSI}

- Mengubah cara pandang, pikiran, sikap, perilaku untuk berorientasi pada kemajuan dan kemodernan,

- Gerakan kolektif yang melibatkan seluruh komponen bangsa dengan memperkuat peran institusi pemerintahan dan pranata sosialbudaya di masyarakat.

- Internalisasi nilai-nilai esensial pada individu, keluarga, insititusi sosial, masyarakat dan lembaga negara.

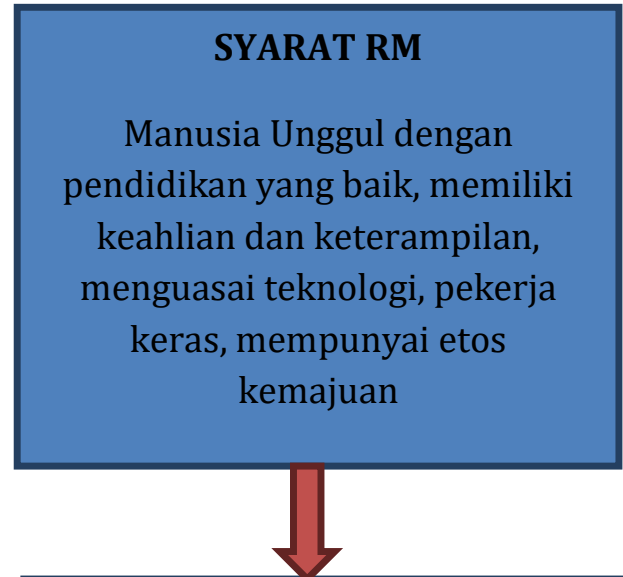

NILAI-NILAI ESENSIAL RM Integritas

-Jujur, Dapat Dipercaya,

Berkarakter, Bertanggungjawab Etos Kerja

-Kerja keras, optimis, produktif, inovatif, dan berdaya saing

Gotong Royong

-Bekerjasama, Solidaritas Tinggi,

Komunal, Berorientasi pada

Kemaslahatan, Kewargaan

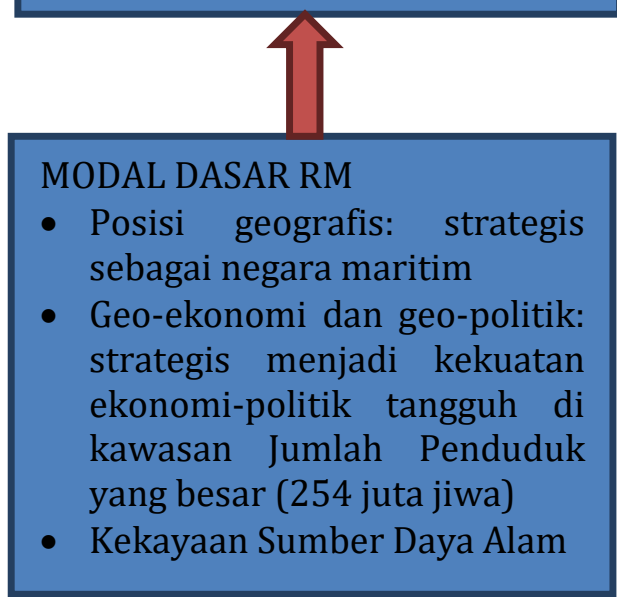

HASIL AKHIR

Bangsa Indonesia yang maju, modern, makmur, sejahtera \& bermarta bat

\section{Pendidikan Karakter Melalui Revolusi Mental Di Era Disruptif}

Pendidikan karakter adalah pendidikan yang mengembangkan nilai budaya dan karakter bangsa yang memiliki nilai-nilai baik dalam karakter dirinya. Menerapkan nilai-nilai karakter dalam kehidupannya sebagai warga 
negara yang religius, nasionalis, produktif, kreatif di anggota masyarakat.47Dalam proses pembentukan pendidikan karakter pemerintah dan mayarakat lebih serius lagi dalam menanggulangi fenomena yang terjadi dikalangan masyarakat yang terjadi dibangsa negara.

Di era disruptif ini ada 5 bagian Pendidikan karakter melalui revolusi mental dalam menanggulangi fenomena yang terjadi pada bangsa Indonesia ini yakni; yakni cara berpikir (pola pikir), cara meyakini (spiritual-hati), cara bersikap dan berperilaku (sopan santun dan budi pekerti), jujur disertai tanggung jawab, dan kerja keras. ${ }^{48}$

a. Cara berpikir (pola pikir)

Inti dari pemikiran manusia adalah pola pikir dimana otaklah yang berfungsi untuk menyaring atau tidaknya suatu keputusan. Setelah informasi disaring maka suatu keputusan ditentukan oleh pola pikir seseorang tersebut. ${ }^{49}$ Didalam kurikulum 2013 berpikir yakni salah satu tujuan pembelajaran yang meningkatkan kemampuan berpikir kritis. Dimana peserta didik sudah terbiasa dalam berpikir. Sehingga peserta didik bisa berpikir semakin kritis, dengan mengambil keputusan yang harus diyakini dan dilakukan. ${ }^{50}$

Prior research has shown that mindset has an impact on resilience. Individuals, who believe that they are not defined by their past behavior and can change and develop, are better able to respond to challenging situations. They perceive difficultsituations and setbacks as opportunities to learn and grow. When individuals believe that theycan alter basic traits by making an effort, they are motivated to give their best and amelioratethose traits. ${ }^{51}$

Sudah terbukti bahwa pola pikir dapat berubah dan berkembang. Jika, peserta didik sering berlatih, berusaha dan semangat belajar maka olah pikir atau pemikiran bisa berkembang bahkan semakin kritis, karena sudah terbiasa latihan. Jika sebaliknya jika peserta didik jarang melakukan latihan bahkan bermalas-malasan maka olah pikir tersebut tetap, bahkan semakin tumpul.

\footnotetext{
${ }^{47}$ Nur Ainiyah, “Pembentukan Karakter Melalui Pendidikan Agama Islam.”Hal. 27.

48Maragustam, 'Paradigma Revolusi Mental', Jurnal Pendidikan Islam, Xii.Desember (2015), 161-76.

499 Pola Pikir Mahasiswa Dalam Menyelesaikan Permasalahan Pada Mata Kuliah Persamaan Diferensial Diferensial, 'Merisa Kartikasari', Http://Eprints.Ums.Ac.Id/32896/9/Artikel\%20publikasi., 2015.

${ }^{50}$ Eka Puspitasari And Others, 'Integrasi Berpikir Kritis Dan Peduli Lingkungan Melalui Pembelajaran Geografi Dalam Membentuk Karakter Peserta Didik Sma', Jurnal Pendidikan: Teori, Penelitian, Dan Pengembangan, 1.2 (2016), 122-26.

${ }^{51}$ Irma H.M. Renders Marjolein C.J. Caniëls,Judith H. Semeijn, 'Mind The Mindset! The Interaction Of Proactive Personality, Transformational Leadership And Growth Mindset For Engagement At Work', Www.Emeraldinsight.Com/1362-0436.Htm, 2018 <Http://Dx.Doi.Org/10.1108/Cdi-11-2016-0194>. Hal. 2.
} 
Pola pikir dibagi 3 yakni; berpikir tingkat tinggi, berpikir tingkat rendah, dan berpikir kritis. ${ }^{52}$

> berpikir tingkat rendah: Berpikir Tingkat Rendah ialah kemampuan berpikir yang hanya sekedar mengingat apa yang telah terjadi (remembering), mengerti permasalahan yang sedang terjadi (understanding), menerapkan apa yang telah didengar (applying). ${ }^{53}$

$>$ berpikir kritis: Berpikir kritis ialah suatu proses berpikir secara sistematis dalam memahami sebuah informasi sedalam-dalamnya, untuk membentuk suatu keyakinan dengan kebenaran informasi yang sudah diterima dari pendapat yang telah disampaikan. ${ }^{54}$

$>$ Berpikir tingkat tinggi : suatu pemikiran dengan kapasitas tinggi yang diberikan dengan sikap kritis, untuk mengevaluasi apa yang diterima, mempunyai pemahaman dan kesadaran, dan memiliki kemampuan dalam memecahkan suatu masalah. 55

Tugas seorang guru yang mengembangkan pola pikir peserta didik agar pemikiran senantiasa semakin berkembang dan maju. Karena pola pikir bisa senantiasa bertambah ketahap tingkat tinggi seiring latihan dan kebiasaan.

b. Cara meyakini (spiritual-hati)

Spiritualitas yakni sebuah makna yang luas yang ditandai dengan perasaan (hati) kepada sesuatu yang lebih besar dari manusia. Manusia perlu usaha dan pencarian dalam menemukan hakikat tersebut. Semakin dalam perasaan terhubung, semakin pula perasaan menjadi tentram dan damai. ${ }^{56}$ Spiritual adalah suatu kebangkitan atau ketenangan diri dalam mencapai tujuan hidup yang diinginkan. Manusia yang mempunyai nilai spiritual atau keyakinan kepada sang pencipta maka ruh dan jiwa yang berada didalam tubuhnya akan merasa damai dan tentram. ${ }^{57}$

\footnotetext{
${ }^{52} \mathrm{R}$ Rosnawati, 'Berpikir Kritis Melalui Pembelajaran Matematika Untuk Mendukung Pembentukan Karakter Siswa', Seminar Nasional Pendidikan Yogyakarta - Staff.Uny.Ac.Id, 2012, 1-9.

${ }^{53}$ Kus Andini Purbaningrum, "Kemampuan Berpikir Tingkat Tinggi Siswa Smp Dalam Pemecahan Masalah Matematika Ditinjau Dari Gaya Belajar" 10, no. 2 (2017): 40-49.Hal. 41.

${ }^{54}$ Edy Surya Zuhur Fardani, 'Meningkatkan Kemampuan Berpikir Kritis Dalam Pembelajaran Matematika Untuk Membangun Karakter Bangsa', 2017. Hal. 4.

${ }^{55}$ Purbaningrum, "Kemampuan Berpikir Tingkat Tinggi Siswa Smp Dalam Pemecahan Masalah Matematika Ditinjau Dari Gaya Belajar."Hal. 41.

56Iwan Ardian, 'Konsep Spiritualitas Dan Religiusitas ( Spiritual And Religion ) Dalam Konteks Keperawatan Pasien Diabetes Melitus Tipe 2', Jurnal Keperawatan Dan Pemikiran Ilmiah, 2.5 (2016), 19. Hal. 4.

${ }^{57}$ Nefi Aris A Asmara Listiani, Teni, Wahyudin, 'Tingkat Pemahaman Dan Penerapan Nilai-Nilai Spiritual Pegawai Di Balai Pendidikan Dan Pelatihan Keagamaan Bandung', Jurnal Iimu Administrasi, Xiv.2 (2017), 300-313.Hal. 304.
}

79 | MODELING, Volume 6, Nomor 1, Maret 2019 
Nilai-nilai spiritual dibangun dari sebuah kepercayaan. Dimana hubungan manusia secara roh dan jiwa menyambung kepada sang pencipta sehingga seseorang dapat mengaplikasikan dilingkungan masyarakat ataupun dikehidupan sehari-hari sehingga dapat membangun terbentuknya karakter dalam meyakini Tuhan Yang Maha Esa.58 Memiliki nilai spiritual berarti mempunyai ikatan kepada roh dan jiwa. Spiritualisme merupakan salah satu aspek penting dan berpengaruh besar dalam pendidikan karakter, dengan keyakinan kepada Tuhan Yang Maha Esa dapat membentuk karakter peserta didik membentuk manusia yang berkepribadian yang baik, membiasakan bersikap baik kepada sesama makhluk hidup ciptaan tuhan, berperilaku dan bergaul dengan menghormati dan menghargai meski berbeda keyakinan, beramal bagi orang yang membutuhkan, saling membantu dan menolong. ${ }^{59}$

Dalam penanaman nilai spiritual menjadi dasar sebuah pondasi peserta didik dalam memerangi tantangan era disruptif. Pendidikan dan karakter sangat besar pengaruhnya karena semua berjalan dengan beriringan. Adanya spiritualisme menanamkan perubahan yang terjadi dinegara indonesia demi berkualitasnya kesejahteraan dengan kemajuan teknologi yang semakin dasyat. 60

Spiritualisme adalah bagian terpenting dalam proses pembentukan karakter. karena adanya keyakinan kepada Sang Maha Pencipta sesorang bisa menjadi karakter yang lebih baik lagi, pada hakikatnya semakin dekat jiwa dan roh manusia terhadap Tuhannya semakin baik pula tingkah lakunya.

\section{c. Cara bersikap dan perilaku (sopan santun dan berbudi pekerti)}

Sopan santun adalah perilaku seorang yang menjunjung tinggi dalam berperilaku; menghormati, menghargai, dan tidak sombong. Perilaku dari sikap sopan yakni melalui komunikasi menggunakan bahasa yang tidak meremehkan atau merendahkan sehingga membuat seseorang tidak tersinggung. ${ }^{61}$

Selain bersikap sopan santun ada budi pekerti yang merupakan sikap sesorang. Budi pekerti berkaitan dengan norma etika yang didalamnya mengandung nilai-nilai sikap seseorang yang akan dilihat dari baik buruknya

\footnotetext{
58Ibid. Hal. 304.

${ }^{59}$ Fathul Mufid, "Spiritual Teaching Dalam Membentuk Karakter Siswa Di Smk Islam Tsamratul Huda Tahunan Jepara,” Edukasia: Jurnal Penelitian Pendidikan Islam 11, no. 2 (2016): 253-276.

${ }^{60}$ Hidayatu Rokhmah, 'Penanaman Nilai-Nilai Spiritual Terhadap Peserta Didik Di Sd It Harapan Bunda Purwokerto Jurusan Pendidikan Agama Islam Fakultas Tarbiyah Dan Ilmu Keguruan Institut Agama Islam Negeri ( Iain ) Purwokerto', 2016, 1-100.

${ }^{61}$ Sunu Dwi Antoro Ujiningsih, "Pembudayaan Sikap Sopan Santun Di Rumah Dan Di Sekolah Sebagai Upaya Untuk Meningkatkan Karakter Siswa *," Jurnal PGSD: Jurnal Ilmiah Pendidikan Guru Sekolah Dasar 10, no. 1 (2017): 27-36.
} 
norma agama, hukum, budaya/adat istiadat, tata krama, disuatu masyarakat atau bangsa. ${ }^{62}$ Budi pekerti dilakukan melalui contoh keteladanan bagi orang tua atau guru sehingga dapat membentuk anak atau peserta didik tersebut.63Budi pekerti juga suatu upaya untuk memberi pengetahuan melalui bimbingan dan latihan dalam pertumbuhan dan perkembangan dalam dirinya sebagai bekal masa depan agar memiliki perilaku yang baik berupa perkataan, pola pikir, perbuatan berdasarkan nilai-nilai agama dan norma. ${ }^{64}$

Sopan santun dan budi pekerti adalah sesuatu yang berjalan beriringan, sopan santun cara seseorang berperilaku, sedangkan budi pekerti cara seseorang untuk bersikap.

d. Tanggung jawab disertai jujur

Tanggung jawab merupakan penanaman karakter yang merupakan sikap dan perilaku dalam melaksanakan kewajiban dan tugasnya sebagai makhluk hidup yang seharusnya dilakukan diri sendiri, keluarga ataupun masyarakat.650rang yang melaksanakan tugas dan kewajiban dengan kesadaran tinggi maka seseorang dapat dikatakan baik. Orang yang didalam hatinya mempunyai rasa tanggung jawab besar terhadap dirinya sendiri ataupun orang lain maka ia akan sanggup mempertanggung jawabkan perbuatan yang telah dilakukannya. ${ }^{66}$

Jujur adalah mengatakan apa adanya dalam bersikap dan berperilaku dengan kenyataan yang sebenar-benarnya dan menjadikan dirinya sebagai orang yang dapat dipercaya dalam tindakan ataupun perkataannya. ${ }^{67}$ Penanaman karakter jujur adalah suatu hal penting dalam mengembangkan karakter pada anak usia dini. Karena karakter lebih mudah dibentuk sejak usia dini. Pihak yang berperan dalam pembentukan dan penanaman karakter kejujuran yakni orang tua, guru dan lingkungan masyarakat. Dengan memberikan contoh yang baik atau hal-hal yang positif, dapat menunjang pembentukan karakter. bukan anak-anak usia dini saja melainkan seluruh masyarakat bangsa Indonesia juga wajib menanamkan sifat kejujuran. Dengan kebiasaan dan mempraktekan hal-hal positif dalam

\footnotetext{
${ }^{62}$ Ali Muhtadi, "Strategi Untuk Mengimplementasikan Pendidikan Budi Pekerti Secara Efektif Di Sekolah," staffnew.uny.ac.id, no. 4 (2012): 1-13.

${ }^{63}$ Sulthoni, 'Penanaman Nilai-Nilai Budi Pekerti Di Sekolah Dasar', 2.November (2016), 100-108.

${ }^{64}$ Hadiwinarto, "Analisis Faktor Hasil Penilaian Budi Pekerti," Jurnal Psikologi 41, no. 2 (2014): 229240.

65Rizka Puji Rahayu, 'Implementasi Pembelajaran Nilai Tanggung Jawab Pada Siswa Kelas Iii Sd 1 Pedes Sedayu Bantul Tahun Pelajaran 2014/2015', Jurnal Pendidikan Guru Sekolah Dasar, 2.5 (2016), 152-60.

${ }^{66}$ Ahmad Wahyu Adi Prabowo, 'Implementasi Nilai-Nilai Karakter Tanggung Jawab Dalam Pembelajaran Akidah Akhlak Peserta Didik Di Mtsn Sumberagung Bantul Yogyakarta', 2014, 1-102.

${ }^{67}$ Muhammad Amin, 'Peran Guru Dalam Menanamkan Nilai Kejujuran Pada Lembaga Pendidikan', Tadbir: Jurnal Studi Manajemen Pendidikan, 1.1 (2017), 105-24.
}

81 | MODELING, Volume 6, Nomor 1, Maret 2019 
kehidupan sehari-hari adalah salah satu tips agar seorang terbiasa apa yang dia lakukan, tanpa adanya perencanaan. ${ }^{68}$

Sosok guru harus membiasakan peserta didiknya agar mereka mempunyai kepribadian Tanggung jawab dan jujur, karena dengan perilaku tersebut bisa menjadikan manusia berbudi luhur, menjadikan manusia yang berkualitas serta mempunyai nilai-nilai sesuai dengan norma dan agama.

e. Kerja keras

Kerja keras adalah sifat kemandirian yang harus ditanamkan bagi peserta didik, karena dengan ini, seseorang tidak merasa ketergantungan pada orang lain contohnya dalam mengerjakan soal-soal ujian ketika peserta didik berkerja keras dalam belajar atau bersungguh-sungguh , secara tidak langsung menanamkan nilai kemandirian pada dirinya. Untuk memulai kebiasaan mandiri maka sosok guru dan orang tua diperlukan kerja keras untuk mencapai tujuan yang diinginkan. ${ }^{69}$

Revolusi mental dapat menghasilkan bangsa yang unggul dan berkualitas dalam bidang pendidikan di era disruptif. ${ }^{70}$ Penulis menginginkan indonesia yang berkepribadian cerdas dalam berpikir (pola pikir), cara meyakini (spiritual-hati), cara bersikap dan berperilaku (sopan santun dan budi pekerti), jujur disertai tanggung jawab, dan kerja keras yang dapat dirasakan bangsa negara Indonesia nantinya. Selanjutnya didukung oleh kepemerintahan yang bijak. Tidak ada lagi tawuran-tawuran, narkoba, pelecehan seksual, korupsi dan kasus-kasus tercela lainnya.

\section{Kesimpulan}

Pendidikan karakter yang ada dilembaga formal khususnya sekolah memiliki tujuan tersendiri yakni mempererat dalam mengembangkan nilainilai kehidupan, mengoreksi perilaku peserta didik yang tidak sesuai bagi nilainilai dan norma, membangun komunikasi yang baik dengan keluarga maupun masyarakat demi menjadi kepribadian yang baik dan menanamkan tanggung jawab khususnya bagi para generasi anak bangsa untuk terbentuknya pendidikan karakter.

Pendidikan karakter bukanlah suatu materi yang bisa dibaca atau dicatat dan juga tidak dapat dievaluasi dalam jangka waktu yang singkat,melainkan sebuah pembelajaran yang diterapkan dalam kehidupan sehari-harinya kepada peserta didik. Baik dilingkungan sekolah, lingkungan keluarga ataupun

\footnotetext{
${ }^{68}$ Fety Irawan, 'Penanaman Karakter Kejujuran Pada Anak Usia Dini (Studi Kasus Di Desa Cemeng Kecamatan Sambungmacan Kabupaten Sragen)', 2014, 1-11.Hal. 10.

${ }^{69}$ Nita Warih Handayani Dan Sumaryati, 'Upaya Orang Tua Dalam Menanamkan Karakter Kerja Keras Anak Usia Remaja Di Dusun Tegalyoso Banyuraden Gamping Sleman Yogyakarta', Jurnal Citizenship, 4.1 (2014). Hal. 35.

70Kristiawan, "Telaah Revolusi Mental Dan Pendidikan Karakter Dalam Pembentukkan Sumber Daya Manusia Indonesia Yang Pandai Dan Berakhlak Mulia."(2017) Hal. 22.
}

MODELING, Volume 6, Nomor 1, Maret 2019 | 82 
lingkungan masyarakat melalui proses pembiasaan, keteladanan yang dilakukan secara berkesinambungan. Tugas dan sebuah tanggung jawab antara orang tua, guru, masyarakat bangsa dalam proses berhasilnya pendidikan karakter. Pembangunan karakter merupakan cita-cita bangsa Indonesia yang didasari oleh pancasila UUD 1945.

Semenjak pemerintahan baru jokowi istilah revolusi mental bukanlah suatu yang asing lagi. Mental tentang pikiran. Mentalitas juga berkaitan dengan cara pikir yang menjadi kebiasaanya dalam berpikir, kebiasaan dilakukan karena dengan pembiasaan. jadi, mentalitas dapat diubah dengan cara melakukan perubahan dari kebiasaan. Sehingga menjadi terbiasa dilakukan dan terjadi secara spontan. Revolusi menurut KBBI ialah suatu perubahan, Mental dapat diartikan cara pola pikir, cara memandang masalah, cara berperilaku dan bertindak. Makna luasnya revolusi mental adalah membongkar budaya-budaya yang sudah tertanam kuat kini menjadi hilang. salah satunya sifat tidak bertanggung jawab, banyak peserta didik yang mengadakan tawuran antar pelajar maupun teman sebaya yang mengakibatkan permusuhan bahkan sampai terjadi pembunuhan.

Disruptif adalah sebuah gangguan atau kekuatan mengganggu yang tak terlihat tetapi memiliki kekuatan pengaruh yang luar biasa. Anak lebih senang dengan dunia maya dan teman sebaya di banding berkawan dengan para guru dan orang tua. jika terjadi seperti ini maka peserta didik akan mengalami kesukaran dalam proses pergaulan dengan lingkungan masyarakat yang mengakibatkan kerusakan fatal bagi bangsa Indonesia jika seorang peserta didik tidak bisa memilah dengan kegiatan yang positif. Itulah tantangan bagi guru dan orang tua dalam menghadapi era disruptif.

Dalam proses pembentukan pendidikan karakter pemerintah dan mayarakat lebih serius lagi dalam menanggulangi fenomena yang terjadi dikalangan masyarakat yang terjadi dibangsa negara. Di era disruptif ini ada 5 bagian Pendidikan karakter melalui revolusi mental dalam menanggulangi fenomena yang terjadi pada bangsa Indonesia ini yakni; yakni cara berpikir (pola pikir), cara meyakini (spiritual-hati), cara bersikap dan berperilaku (sopan santun dan budi pekerti), jujur disertai tanggung jawab, dan kerja keras.

\section{DAFTAR REFERENSI}

Ady Ferdian Noor. "Gerakan Revolusi Mental Untuk Meningkatkan Pendidikan Kepribadian Warga Negara." Pedagogik Jurnal Pendidikan 11, no. Maret (2016): 7-13.

Ainiyah, Nur. "Pembentukan Karakter Melalui Pendidikan Agama Islam." Jurnal 
Al-Ulum 13, no. 1 (2013): 25-38.

Ali Muhtadi. "Strategi Untuk Mengimplementasikan Pendidikan Budi Pekerti Secara Efektif Di Sekolah." staffnew.uny.ac.id, no. 4 (2012): 1-13.

Amin, Muhammad. "Peran Guru Dalam Menanamkan Nilai Kejujuran Pada Lembaga Pendidikan." TADBIR: Jurnal Studi Manajemen Pendidikan 1, no. 1 (2017): 105-124.

Baharun, Hasan. "Peningkatan Kompetensi Guru Melalui Sistem Kepemimpinan Kepala Madrasah." At-Tajdid: Jurnal Ilmu Tarbiyah 6, no. 1 (2017): 1-25.

Bahri, Saiful. "IMPLEMENTASI PENDIDIKAN KARAKTER DALAM MENGATASI KRISIS MORAL DI SEKOLAH." Jurnal TA'ALLUM 3, no. 1 (2015): 57-76.

Dalmeri. "Pendidikan Untuk Pengembangan Karakter (Telaah Terhadap Gagasan Thomas Lickona Dalam Educating for Character)." Al-Ulum 14, no. 1 (2014): 269-288. https://www.researchgate.net/publication/290920065_PENDIDIKAN_U NTUK_PENGEMBANGAN_KARAKTER_Telaah_terhadap_Gagasan_Thomas _Lickona_dalam_Educating_for_Character.

Diferensial, Pola Pikir Mahasiswa Dalam Menyelesaikan Permasalahan Pada Mata Kuliah Persamaan Diferensial. "Merisa Kartikasari." http://eprints.ums.ac.id/32896/9/ARTIKEL\%20PUBLIKASI., 2015.

Fatmawati, Endang. "Disruptif Diri Pustakawan Dalam Menghadapi Era Revolusi Industri 4.0." Jurnal Iqra' 12, no. 1 (2018): 1-13.

Hadiwinarto. "Analisis Faktor Hasil Penilaian Budi Pekerti." Jurnal Psikologi 41, no. 2 (2014): 229-240.

Haris Budiman. "Peran Teknologi Informasi Dan Komunikasi Dalam Pendidikan." Al-Tadzkiyyah: Jurnal Pendidikan Islam 8, no. 1 (2017): 3143.

Haryati, Sri. "Pendidikan Karakter Dalam Kurikulum 2013." http://lib. untidar. ac. id/wp, 2017.

Herwina, Iswan dan. "Penguatan Pendidikan Karakter Perspektif Islam Dalam Era Milineal IR. 4.0." PROSIDING Seminar Nasional Seminar Nasional Pendidikan Era Revolusi "Membangun Sinergitas dalam Penguatan Pendidikan Karakter pada Era IR 4.0" Universitas Muhammadiyah Jakarta, Indonesia, 24 Maret 2018 ISSN : 2621-6477 “Membangun Sinergitas dalam Penguata (2018): 21-42.

Indonesia, Republik. "Presiden Republik Indonesia." INSTRUKSI PRESIDEN REPUBLIK INDONESIA NOMOR 12 TAHUN 2016 TENTANG GERAKAN NASIONAL REVOLUSI MENTAL, no. 12 (2016): 1-9.

Irawan, Fety. "Penanaman Karakter Kejujuran Pada Anak Usia Dini (Studi Kasus Di Desa Cemeng Kecamatan Sambungmacan Kabupaten Sragen)" 
(2014): 1-11.

Iwan Ardian. "Konsep Spiritualitas Dan Religiusitas ( Spiritual And Religion )

Dalam Konteks Keperawatan Pasien Diabetes Melitus Tipe 2." Jurnal Keperawatan dan Pemikiran Ilmiah 2, no. 5 (2016): 1-9.

Jenderal, Direktorat, Komunikasi Publik, and Kementerian Komunikasi. REVOLUSI MENTAL, 2015.

Kesehatan, Kementerian, and Republik Indonesia. "Revolusi Mental: Membangun Jiwa Merdeka Menuju Bangsa Besar." www.depkes.go.id, 2018.

Khaliq, Abd. "Pendidikan Karakter Dalam Perspektif Kitab Ayyuhal Walad, Konstruksi Pemikiran Imam Al-Ghazali." Al-Ibrah 2, no. Mei (2017): 88112.

Kristiawan, Muhammad. "Telaah Revolusi Mental Dan Pendidikan Karakter Dalam Pembentukkan Sumber Daya Manusia Indonesia Yang Pandai Dan Berakhlak Mulia." jurnal ta'dib (2015).

Kurniawan, Riza Yonisa. "Identifikasi Permasalahan Pendidikan Di Indonesia Untuk Meningkatkan Mutu Dan Profesionalisme Guru." Konvensi Nasional Pendidikan Indonesia (KONASPI) VIII, no. October (2016): 1415-1420.

Lili Ng Chui Mi. "Pelaksanaan Supervisi Klinis Kepala Sekolah Untukmeningkatkan Kinerja Guru Dalam Mengelola Pembelajaran Pada Sma Negeri 2 Sambas." Jurnal Visi Ilmu Pendidikan (N.D.): 711-723.

Listiani, Teni, Wahyudin, Nefi Aris A Asmara. "Tingkat Pemahaman Dan

Penerapan Nilai-Nilai Spiritual Pegawai Di Balai Pendidikan Dan Pelatihan Keagamaan Bandung." Jurnal Iimu Administrasi Xiv, No. 2 (2017): 300-313.

Maragustam. "Paradigma Revolusi Mental." Jurnal Pendidikan Islam XII, no. Desember (2015): 1"Kemajuan Teknologi Dan Pola Hidup Manusia Dalam Perspektif Sosial Budaya.61-176.

Marjolein C.J. Caniëls,Judith H. Semeijn, Irma H.M. Renders. "Mind the Mindset! The Interaction of Proactive Personality, Transformational Leadership and Growth Mindset for Engagement at Work." www.emeraldinsight.com/1362-0436.htm, no. January (2018).

Mucharomah, Miftah. "Guru Di Era Milenia Dalam Bingkai Rahmatan Lil Alamin." Edukasia Islamika 2, no. 2 (2017): 201-221.

Mufid, Fathul. "Spiritual Teaching Dalam Membentuk Karakter Siswa Di Smk Islam Tsamratul Huda Tahunan Jepara." Edukasia: Jurnal Penelitian Pendidikan Islam 11, no. 2 (2016): 253-276.

Muhamad, and Ngafifi." Jurnal pembangunan pendidikan 2, no. 1 (2014): 33-47. Muhammad kristiawan. "Telaah Revolusi Mental Dan Pendidikan Karakter 
Dalam Pembentukkan Sumber Daya Manusia Indonesia Yang Pandai Dan Berakhlak Mulia." jurnal ta'dib 18, no. juni (2015): 14-25.

Muhammad Kristiawan. "Telaah Revolusi Mental Dan Pendidikan Karakter Dalam Pembentukkan Sumber Daya Manusia Indonesia Yang Pandai Dan Berakhlak Mulia." Jurnal Ta'dib 18, no. 1 (2015): 13-25.

Muhdi, Senowarsito, Listyaning S. "Pendidikan Kecakapan Hidup ( Life Skills ) Melalui Child Friendly Teaching Model ( Cftm ) Sebagai Dasar Membangun Karakter Siswa." E-DIMAS Jurnal pengabdian kepada masyarakat 3, no. 1 (2012).

Murniati, Juliana. "Era Disrupsi: Tantangan Dan Peluang Bagi PT Anggota APTIK II . Era Disrupsi Dan Tantangannya Pada Pendidikan" (2017): 112.

Mutmainnah. "Kontribusi Pola Asuh Orang Tua Dalam Pendidikan Karakter." DIKLUS Jurnal Pendidikan Luar Sekolah 16, no. 2 (2012).

Nasrullah. "Pembentukan Karakter Siswa Melalui Pendidikan Agama Islam" 18, no. juni (2015): 67-82.

Nawawi, Ahmad. "Pentingnya Pendidikan Nilai Moral Bagi Generasi Penerus." INSANIA (Jurnal Pemikiran Alternatif Kependidikan) 16, no. 2 (2011).

Nita Warih Handayani dan Sumaryati. “Upaya Orang Tua Dalam Menanamkan Karakter Kerja Keras Anak Usia Remaja Di Dusun Tegalyoso Banyuraden Gamping Sleman Yogyakarta." Jurnal Citizenship 4, no. 1 (2014).

Nur Ainiyah. "Pembentukan Karakter Melalui Pendidikan Agama Islam." Jurnal Al-Ulum (Jurnal Studi-Studi Islam) IAIN Gorontalo 13, no. juni (2013): 2538.

Persada, Nova Mega, and Suwito Eko Pramono. "Pelibatan Orang Tua Pada Pendidikan Anak Di SD Sains Islam Al Farabi Sumber Cirebon" 6, no. 405 (2017): 100-108.

Prabowo, Ahmad Wahyu Adi. "Implementasi Nilai-Nilai Karakter Tanggung Jawab Dalam Pembelajaran Akidah Akhlak Peserta Didik Di Mtsn Sumberagung Bantul Yogyakarta" (2014): 1-102.

Purbaningrum, Kus Andini. "Kemampuan Berpikir Tingkat Tinggi Siswa Smp Dalam Pemecahan Masalah Matematika Ditinjau Dari Gaya Belajar" 10, No. 2 (2017): 40-49.

Puspitasari, Eka, Ach Amirudin, Pendidikan Geografi, And PascasarjanaUniversitas Negeri Malang. "Integrasi Berpikir Kritis Dan Peduli Lingkungan Melalui Pembelajaran Geografi Dalam Membentuk Karakter Peserta Didik Sma." Jurnal Pendidikan: Teori, Penelitian, Dan Pengembangan 1, No. 2 (2016): 122-126.

Rachmah, Huriah. "Nilai-Nilai Dalam Pendidikan Karakter Bangsa Yang Berdasarkan Pancasila Dan Uud 1945." E-Journal widya Non-Eksakta 1, 
no. 1 (2013): 7-14.

Rahayu, Rizka Puji. "Implementasi Pembelajaran Nilai Tanggung Jawab Pada Siswa Kelas III SD 1 Pedes Sedayu Bantul Tahun Pelajaran 2014/2015." Jurnal Pendidikan Guru Sekolah Dasar 2, no. 5 (2016): 152-160.

Revolusi, Gerakan, Mental Pemerintahan, Jokowi Jk, Revolusi Mental, Orde Baru, Revolusi Mental, Jokowi Jk, Revolusi Mental, Presiden Joko Widodo, and Sekretariat Jenderal Dpr. "Membumikan Revolusi Mental." Jurnal Borneo Administrator 11, no. 1 (2016): 121-128.

Rokhmah, Hidayatu. "Penanaman Nilai-Nilai Spiritual Terhadap Peserta Didik Di Sd It Harapan Bunda Purwokerto Jurusan Pendidikan Agama Islam Fakultas Tarbiyah Dan Ilmu Keguruan Institut Agama Islam Negeri ( Iain ) Purwokerto" (2016): 1-100.

Rosnawati, R. "Berpikir Kritis Melalui Pembelajaran Matematika Untuk Mendukung Pembentukan Karakter Siswa." Seminar Nasional Pendidikan Yogyakarta - staff.uny.ac.id (2012): 1-9.

Shodiq, Sadam Fajar. "Pendidikan Karakter Melalui Pendekatan Penanaman Nilai Dan Pendekatan Perkembangan Moral Kognitif." At-Tajdid : Jurnal Ilmu Tarbiyah 1, no. 1 (2017): 14-25.

Sudibyo, Lies. "Peranan Dan Dampak Teknologi Informasi Dalam Dunia Pendidikan Di Indonesia." Widyatama 20, no. 2 (2011): 175-185.

sugiyatno. "Kekerasan Di Sekolah Bagian Masalah Pendidikan SosialEmosional." Paradigma 9, no. V (2010): 29-42.

Sulthoni. "Penanaman Nilai-Nilai Budi Pekerti Di Sekolah Dasar" 2, no. November (2016): 100-108.

Suparno, Paul. "Pengembangan Karakter Untuk Anak Zaman Sekarang." https://core.ac.uk/download/pdf/45364404., 2012.

supinah, ismu tri parmi. "Pengembangan Pendidikan Budaya Dan Karakter Bangsa Melalui Pembelajaran Matematika Di SD." Kementerian Pendidikan Nasional Badan Pengembangan Sumber Daya Manusia Pendidikan dan Penjaminan Mutu Pendidikan Pusat Pengembangan dan Pemberdayaan Pendidik dan Tenaga Kependidikan (PPPPTK) Matematika (2011).

Sutardi, Dodo. "Revolusi Mental Pada Lingkungan Pendidikan Desa Terpencil." Sekolah Dasar: Kajian Teori Dan Praktik Pendidikan, No. 1 (2017): 59-68. Sutono, Agus. "Meneguhkan Pancasila Sebagai Filsafat." Jurnal Ilmiah Civis 1, No. Januari (2015): 666-678.

Suyitno, Imam. "Pengembangan Pendidikan Karakter Dan Budaya Bangsa Berwawasan Kearifan Lokal." Jurnal Pendidikan Karakter 1, no. februari (2012): 1-13.

Syaifudin, Mohammad, Nurul Zuriah, and Marhan Taufik. "Revolusi Mental 
Melalui Model Pendidikan Karakter Bangsa Untuk Penguatan Kemandirian Pangan Dan Cinta Produk Indonesia." Jurnal Pendidikan Sains Sosial dan Kemanusiaan 9, no. November (2016): 221-234.

Ujiningsih, Sunu Dwi Antoro. "Pembudayaan Sikap Sopan Santun Di Rumah Dan Di Sekolah Sebagai Upaya Untuk Meningkatkan Karakter Siswa *." Jurnal PGSD: Jurnal Ilmiah Pendidikan Guru Sekolah Dasar 10, no. 1 (2017): 27-36.

Yuristia, Adelina. "' Keterkaitan Pendidikan, Perubahan Sosial Budaya, Modernisasi Dan Pembangunan."' Jurnal Program Studi Pendidikan Ilmu Pengetahuan Sosial 1, No. 1 (2017): 1-17.

Zuhur Fardani, Edy Surya. "Meningkatkan Kemampuan Berpikir Kritis Dalam Pembelajaran Matematika Untuk Membangun Karakter Bangsa," no. December (2017). 